\title{
中国宋・元時代の禅宗寺院における衆寮に関する研究 A STUDY ABOUT THE SHURYO IN THE ZEN BUDDHISM TEMPLES OF SOONG AND YUAN DYNASTY OF CHINA
}

\author{
韓 志 晚* \\ Jiman HAN
}

\begin{abstract}
The purpose of this study is to clarify the function, architectural composition, scale, the placement in temple, and the formation time of the Shuryo(衆寮) in Zen Buddhism temple of Soong and Yuan dynasty. The historic materials used for this study are the rules(清規) and pictorial record of south Soong dynasty(五山十刹図) of Zen Buddhism temple, analects of Zen priest. And this research brought out four important results like follow: (1) The priests had individual seat at both Sodo(僧堂) and Syuryo. And the Shuryo was used for reading sutra and daily life space. (2) The Shuryo had the court yard in the building for lighting, and supporting space in the rear for needlework, tonsure and so on. And the Shuryo was built as same scale to the inner hall of Sodo for admitting all priests of temple. (3) The Shuryo was placed in the west area of temple and near to Sodo. And in the east area, there were Anjyado(行者堂) and Anjyaryo(行者寮) similar to Sodo and Shuryo, but those were the space for ascetics who didn't became the regular priest yet. (4) The Shuryo of Zen Buddhism temple, take the form as described above, was formatted in the north Soong dynasty at the latest.
\end{abstract}

Keywords : Soong and Yuan dynasty, Zen Buddhism temple, Shuryo, function, architectural composition, scale, placement 宋 - 元時代、禅宗寺院、衆寮、機能、建築構成、規模、伽藍配置

\section{1.はじめに}

東アジア注11 禅宗史からみて、中国の宋・元時代の禅宗寺院が、当 時の日本および韓国などの周辺国における禅宗伽藍の成立および発 展に大きな影響を及ぼしたことで、非常に重要な意味をもつのは周 知の事実である。それのみならず、宋・元時代の禅宗寺院は、中国 仏教史のなかで禅宗仏教が最も盛んになった時期において、完備さ れた禅宗伽藍としての特徵をもっとも良くあらわしている。

この時期の禅宗寺院には、大衆すなわち修行僧たちのための修 行・生活の場として、僧堂と共に衆寮という堂宇が存在していた。 禅宗寺院における僧堂が、修行僧の坐禅・食事・睡眠の場であるの に対して、衆寮は食後に経典祖録の看読、晚の食事、また臨時に茶 湯を喫む堂宇として知られている注2 2 。またこのような衆寮は、何よ りも坐禅弁道を通して悟りの開きを求める修行僧を本位とする、禅 宗の宗旨からみると、当時の禅宗伽藍を成す一要素として注目する べき堂宇といえる。

現在まで、禅宗伽藍を構成する堂宇としての衆寮に関する建築史 分野での研究は、横山秀哉の研究注3)がほぼ唯一である。横山氏は主 に衆寮における経典祖録の看読という機能に意味を置き、行(坐禅修 行)の道場としての僧堂に対して、学(経典祖録の看読)の方面の機能 をあらわす堂宇が衆寮で、僧堂に従属するものとして位置付けた。 また、中国の禅宗寺院における衆寮の成立時期においては、衆寮と
いう堂宇そのものは北宋中期頃には成立していたが、衆寮における 経典祖録の看読という機能は南宋時代から始まったという注4)。

一方、最近になって中国においても、主に「五山十刹図」注5)に基づ いた南宋時代の禅宗寺院に関する研究成果が出されてはいるが、未 だ日本における研究成果を超えているとは評価し難い注6)。

しかし、清規などの関連史料を再検討すると、既存研究で指摘さ れている衆寮の成立時期については多少の疑問が残る。また衆寮の 建築形態や規模に係わる機能についても、主に経典祖録の看読に着 目した既存研究で見過ごされているところがある。なお、既存研究 で全く触れられなかった伽藍配置上にあらわれる特徴についても考 察する必要がある。

以上の問題意識を持って本研究では、清規類、禅僧の語録、そし て「五山十刹図」といった史料を用いて、宋・元時代の禅宗寺院にお ける衆寮の機能、建築構成と規模、伽藍におけるその位置関係、ま た衆寮の成立時期を、明らかにすることを目的とする。さらに、当 時の禅宗寺院における衆寮の意味を考えたい。

\section{2. 衆寮の機能}

\section{$2-1$ 新到の掛搭}

新到とは禅院に新しく入る僧のことであり、掛搭とは衣鉢袋を僧 堂の単位の銁に掛ける意味で、行脚の僧が禅院に止住して大衆と起

本論文は, 日本学術振興会から平成19年度科学研究補助金の交付を受けて行った研究成果の一部である。

* 東京大学大学院工学系研究科建築学専攻

博士課程·修士 (工学)

日本学術振興会特別研究員 (DC2)

Graduate Student, Dept. of Architecture, Faculty of Engineering, Univ. of Tokyo, M. Eng. Research Fellow of the Japan Society for the Promotion of Science (DC2) 
居を共にすることである湦7)。このように新到の掛搭は、僧堂におい て単位を定める意味として知られているが、実際に宋・元時代の禅 宗寺院では、僧堂以外に衆寮においても掛搭が行われたことが、清 規から確認される。

北宋崇寧 2 年 (1103)に宗垻が撰した『禅苑清規』注8) (第一巻「掛搭」 条)には、衆寮における新到の掛搭に関する次のような内容がある。 新到帰寮 尋寮主云〈新到相看〉。見寮主、各觸礼三拜。… (中略) … 於是、寮主看詳戒臘高低、指参頭以下、一例就看読床案掛搭。( $>$ : 割注、以下同じ)

これは、新到が禅院に入る時、僧堂での掛搭に次いで、衆寮におい て行われた掛搭の作法である。これによれば、寮主は参頭(新掛搭僧 の代表者) 以下の新到の戒臘の高低を見て、一人々看読の床案につい て掛搭させていることがわかる。そして、僧堂の単位を、睡眠のと きは布団を、二時(朝・昼)の食事のときは鉢を展ずるところの意味 で「被位」または「鉢位」とも称したことに対して、衆寮の単位は「看読 の床案」であったことが注目される。なお、新到が禅院に入る時に、 僧堂と衆寮の両方において掛搭が行われたことは、元の至元 4 年 (1 338)に東陽徳輝が撰した『栜修百丈清規』からも確認できる注9)。

このように、宋・元時代の禅宗寺院における修行僧は、僧堂と衆 寮の両方において各自の単位を定めてもらったのである。しかし、 清規に記寸僧堂及び衆寮に係わる記述をみると、各自の独寮(単寮と も)が与えられていた知事や頭首など役僧の場合は、僧堂には坐禅と 食事とをする単位が設けられていたが、衆寮には役僧の単位がなか ったと考えられる。

\section{2-2 経典祖録の看読}

横山氏が既に指摘したように、衆寮の持つ最も重要な機能は経典 祖録の看読であろう。それ故に、衆寮における修行僧の単位を「看読 の床案」と呼んでいた。一方、横山氏は北宋代の『禅苑清規』から衆 寮の存在は確認できるが、看読に関する記述はないとみて、北宋時 代までは衆寮で看読が行われなかったと考えた注10)。しかし、上述 したように『禅苑清規』によれば、当時の衆寮には「看読の床案」が 設けられており、衆寮における看読の機能は十分考えられる注11)。 ただ、同清規の「蔵主」条(第四巻)には、看経堂における看経の作法 が詳しく記されており、北宋時代までは 看経堂と衆寮の両方におい て看経が行われていたと考えられる。

南宋時代になると常時の看経は、専ら衆寮で行われるようになり 注12)、南宋末の咸淳 10 年 (1274) 惟勉が撰した『叢林校定清規総要』 注13) には蔵殿における看経の作法は見当たらない。また、同清規の 巻下「無量寿禅師日用小清規」(1209 年初刊)には、「帰寮問訊…(中 略) …若有茶、就座…(中略) …茶罷、或看経。不得長展経〈謂二面也〉。 不得手托経寮中行。不得垂経帶。不得出声。不得背靠板頭看経」とあ り、衆寮における看経の作法が詳しく記されている。なお、元の至 元 4 年 (1338)に東陽徳輝が撰した『勅修百丈清規』注14) (卷第四「知 蔵」条)には、「凡看経者。初入経堂、先白堂主。同到蔵司相看。送帰 按位、対觸礼一拜。此古規也。今各僧看経多就衆寮、而蔵殿無設几 案」とあり、蔵殿は几案がなくお経を収めておく経蔵のような堂宇と なり、看経の場となっている衆寮の様子がよく窥える。

一方、経典だけではなく、祖師の語録などの禅籍も衆寮において 看読したことがわかる記録もしばしば散見される。例えば、南宋の
乾道 8 年 (1172)に蓝聞が編集した『大慧普覚禅師語録』注15) (巻第三 十「答鼓山逮長老」条)には、「去年送得一冊語錄來。造次顛沛、不失 臨濟宗旨。今送在衆寮中、與衲子輩看。」とあり、大慧宗杲 (1089-1 163) が送られて来た禅僧の語録を、衆寮において修行僧と共に看読 したという。また、元の廷祐 3 年 (1316)に『景徳伝灯録』(1004 年、 道原撰)を重刊する際に添えられた「重刊景徳伝灯録状」永16)には、 「隨即印。捨三百部於両浙。安衆名山方丈・蒙堂・衆寮各一部。」と 記し、重刊した『景徳伝灯録』を両浙(今の浙江省と江蘇省の一部) 地方に喜捨して、名山の方丈、蒙堂 (勤旧退職の僧の寮舎)および衆 寮に各一部ずつおくようにしていたという。

\section{$2-3$ 法会}

まず、南宋の『叢林校定清規総要』および元の『禅林備用淸規』 注17) (1311 年、式咸撰)によれば、夏安居注18) が始まる前日(結夏、4 月 12 日) と終る前日 (解夏、7 月 12 日)に、衆寮において、安居の無 事円成を祈念寸る楞㛜会注19)が行われている注20)。これらの清規に記 す楞㛜会の内容を概観すると、まず夏安居の期間中に衆寮において 点茶を担う僧(執瓶盛兄弟)の為に、また修行僧の為に湯 (蜜湯)を供 養する。次に住持・知事・頭首も衆寮に入り、安居の無事円成を祈 念してお経(『楞厳経』)を読誦する。なお、安居の期間中には毎日 仏殿において楞厳会が行われ注21)、衆寮においては頭首が大衆に茶 湯を供養する注22)。

一方、北宋の『禅苑清規』には、結夏と解夏の日の晚に土地堂の 前に集まって念誦を行っており注23)、「楞稂会」という法会の名称さ えも清規全体に通して見当たらない。即ち『禅苑清規』が編纂され た北宋の崇寧 2 年 (1103) 頃の段階までは、楞厳会が行われる堂宇と しての機能が、衆寮にはなかったと考えられる。

その他に、『叢林校定淸規総要』(卷下「上堂・普説・小参」条)には、 「洞下尊宿、毎於朔望、升堂罷、就衆寮、當中設位、為兄弟普説」と 記し、「洞下」、即ち曹洞宗の開祖、洞山良价(807-869)の法孫である 尊宿(住持) は、毎月の初日と十五日に衆寮において普説注 24 を行っ たという。

以上のように、南宋・元時代の禅宗寺院における衆寮では、結夏 と解夏の日の晚における楞㛜会、特に曹洞宗の寺院では住持の説法 (普説)などの法会が行われていた。

\section{2-4 日常生活}

一方、宋・元時代の禅宗寺院における衆寮は、修行僧が衣服・鉢 をはじめ様々な私物を置く堂宇でもあった。これに係わって、北宋 の『禅苑清規』から下のような記述が注目される。

- 入寺之法 $\cdots$ (中略) …如便掛搭、於僧堂前門南床上、先仰安笠 子…(中略) …搭袈裟、袖祠部、詣堂司相看、掛搭了。如堂中有 函樌 師收行李安函櫃中錙之。笠子・挂杖帰寮。如堂中無函樻、 收行李赴寮。人事了、聴寮主・首座指授処所、相看畢、掛鉢。 安被於僧堂內。茶筒文字置寮中案上。(第一巻「裝包」条)

- 寮中首座 $\cdots$ (中略) …同寮主於寮中止宿、看守衆僧衣鉢、并特 為新到 (第四巻「寮主・寮首座」条)

即ち新到は、まず僧堂において堂司 (維那) と相看し掛搭を行って自 分の単位を定めてもらう。その時、行李㘧25) は僧堂の各単位に設け られている函櫃に収めておき、笠子・挂杖は寮(衆寮)に持ち帰る。 
もし僧堂に函樌がない場合は行李を衆寮に持って行く。次に衆寮に おいては、寮主・寮首座と相看して掛搭を行い、自分の単位に鉢を 掛け、茶筒・文字(本)などは案上におく。また、寮首座は寮主と共 に衆寮に止宿しながら衆僧の衣鉢を看守するという。ここでは特に、 食事は僧堂で摂るものの、鉢は衆寮に掛けておくことが注目される。 また南宋時代の禅宗寺院では、二時の食事(朝の粥・昼の斎)の他、 北宋の『禅苑清規』までは厳しく禁じられた注26) 薬石 (夕食)も摂る ことになり、そして薬石を摂る場所は僧堂ではなく衆寮であった。 即ち『叢林校定清規総要』(巻下「坐禅・坐堂・放参」条)には「晚下 坐堂。至鳴放参鐘、和南展単、帰寮喫粥」と記し、晚に坐堂(僧堂) を出る際には、放参鐘注27) が鳴ると、和南注28) ・ 展単注29) して、寮 (衆 寮)に帰って粥を喫むという。元時代の『禅林備用清規』(巻之二「坐 参」条) 注30)、『栜修百丈清規』(巻第五「坐参」条) 注31) などからも同じ く、晚に衆寮において薬石を摂ったことが確認できる。一方、南宋 代には放参の時に、住持と頭首などの役僧も大衆と共に衆寮におい て薬石を摂ったが、元代には住持や頭首などの役僧たちはそれぞれ の方丈と寮舎で薬石を摂り、修行僧たちのみが衆寮で薬石を摂るよ うになった注 32 。

禅宗寺院の修行僧において、僧堂での坐禅が修行の最も重要なこ とであろう。僧堂における坐禅修行は、食事・睡眠と共に時間が定 められており注33)、僧堂は何時でも自由に出入ができる堂宇ではな かった。しかし修行僧たちは、僧堂における坐禅、食事、睡眠以外 の時間を過す場所は主に衆寮であったことが、『叢林校定淸規総要』 (巻下「坐禅・坐堂・放参」条) に記寸次の内容からわかる。

- 毎日坐禅。堂司行者、於粥後、先覆首座。鳴衆寮前板、大衆帰 堂坐。

·如放参。申時後…(中略) …鳴衆寮前板、大衆帰堂坐定。 これは毎日の午前中の朝食 (粥) 後の坐禅と、午後の申時 (3-5 時) 後 に坐禅しながら晚参注34) を待つ坐参に関する作法である。午前と午 後の坐禅は、両方とも修行僧が衆寮から出て、僧堂に移って坐禅を している。また鉢は常に衆寮に置かれていたため、朝と昼の僧堂に おける食事の時も、修行僧が衆寮から鉢を持って僧堂に移動したこ とは当然のことであった。即ち修行僧たちは、上述した薬石の時の ほか、僧堂での坐禅や食事・睡眠以外の時間も、基本的に衆寮で過 ごしていた。

なお、後述するが、衆寮には後方に「把針処」、洗衣所、後架 (洗面 所)などが設けられており、把針、即ち縫い物や洗濯、洗面をはじめ 剃髪、合薬など、修行僧の身の回りのことをする場所として使われ ていた。

以上のように、宋・元代の禅宗寺院における衆寮は、専ら坐禅修 行の場所である僧堂では許されなかった、いわば修行僧の日常生活 の側面に係わることが行われていたのである。このように厳しい修 行の場である僧堂とは異なる衆寮の性格は、元初期の雪嚴祖欽 (?-1 287)が双林寺で修行していた期間に、「朝から暮まで、ただ僧堂の中 におり、庭に出ることもなかった。たとえ衆寮に入っても、後架に 至っても、手を袖に入れて胸に当て、ゆっくり往来した」注35) という ことからも窥うことができる。

\section{3. 衆寮の建築構成と規模}

13 世紀中期ころの南宋における禅宗伽藍の様相の記録とされる
注36)「五山十刹図」には、衆寮の平面注37) を描いた図面が一枚収録され ており、南宋時代の禅宗寺院における衆寮の姿が確認できる(図 1 )。 この図に描かれている衆寮は正面 7 間、側面 11 間の大規模で、前(側 面 8 間分) と後の二部分で構成されている。

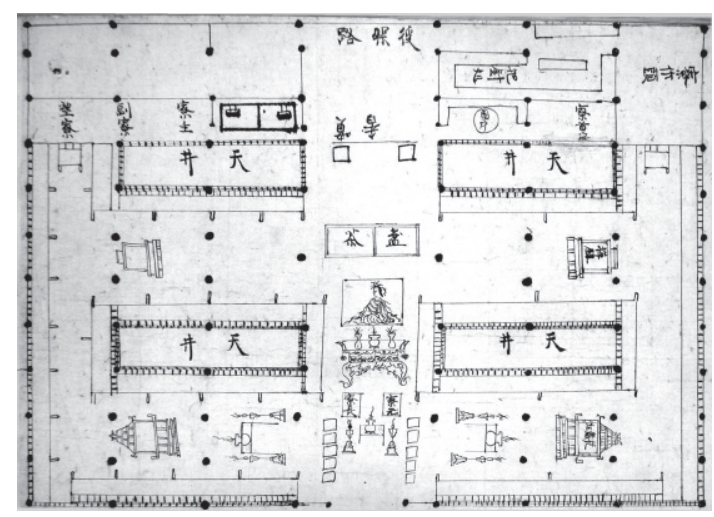

図 1 衆寮平面図(「五山十刹図」、大乗寺本)

前部には中央に聖像(観音)が安置され、それを中心に周り四ヶ所 に「天井」(中庭) が設けられている。外壁と中庭に沿って連床状の単 が取り付けられ、その上には看読用の経案が設けられている。また 右側の通路には、それぞれ「華厳経」と「禅録」と書き込まれている経 典祖録を納める小型の蔵経台が前後に置かれており、左側にも同じ 形の蔵経台が描かれている。さらに聖像の後には点茶の時に使う茶 具を置く台がある。

後部は、衆寮の管理および修行僧の日常生活に係わる様々な補助 的な空間から成る。すなわち「寮作頭」・寮首座」・「寮主」・「副寮」・ 「望寮」など、衆寮に止宿しながら寮の管理を担う役僧の居房、また 「把針処」という、修行僧たちが縫物、剃髪、合薬など身の回りのこ とをする空間がある。なお「五山十刹図」に収録されている霊隠寺(旃 檀林) ・ 天童寺 (照心寮と妙篇堂) ・ 万年寺 (勝集堂)の三つの寺院の伽 藍配置図からも、衆寮の後に寮元の居房、把針処、洗衣所、干衣所 などの空間が設けられている姿が確認できる注38) (図 2)。
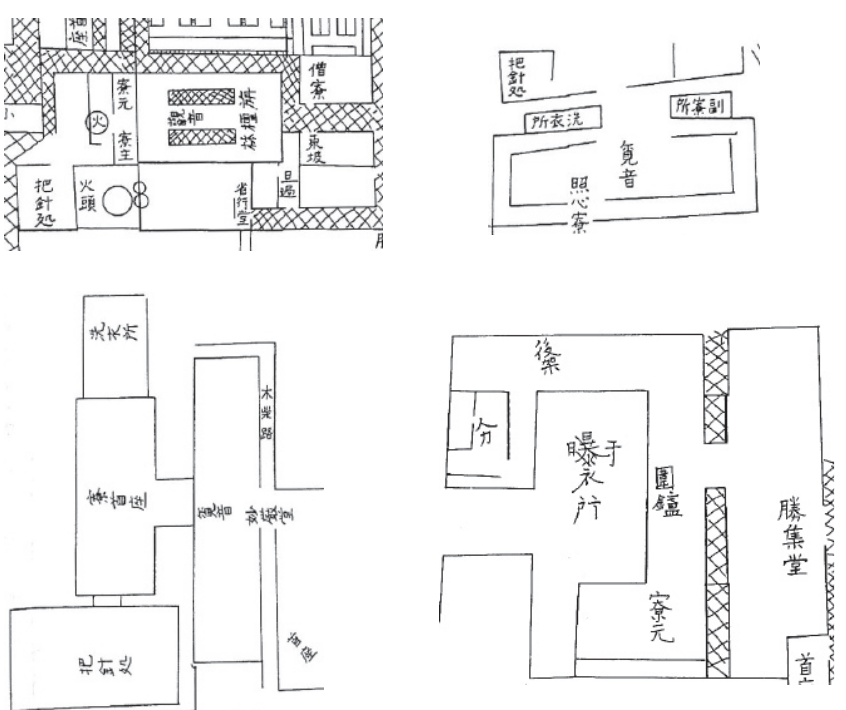

図 2 「五山十刹図」伽藍配置図の衆寮: 霊隠寺「旃檀林」(左上)、天童 寺「照心寮」(右上)・「妙厳堂」(左下)、万年寺「勝集堂」(右下) （東福寺本「大宋諸山図」の図写、関口欣也『五山と禅院』より） 
一方、このように聖像の周りに連牀状の単を設けた衆寮の内部構 成は、一見僧堂と非常に似ている。しかし衆寮の場合、建物の中に 採光のための中庭を設けたことが僧堂と大きく異なる点であり、こ れは経典祖録の看読という機能に符合する。また、知事・頭首など の役僧が坐禅・食事をする単位が設けられる僧堂の「外堂」当る部分 が衆寮にはない。これは、各役僧はそれぞれの寮舎が与えられてい たためであり、睡眠も僧堂ではなく各自の寮舎でとった注39)。

さて、上述のように修行僧たちは、僧堂と衆寮の両方において掛 搭を行い各自の単位を定めてもらっていたことを考えると、衆寮の 規模、即ち収容可能人数は、僧堂、その中でも一般の修行僧たちの 修行の場である「内堂」の規模と密接な関係にあったと推定される。

またこれは衆寮を建てる際における計画基準と係わる問題ともなる ため、ここで収容可能人数を中心に衆寮と僧堂の内堂との規模関係 を検討しておきたい。現在のところ、宋・元時代の禅宗寺院におけ る僧堂と衆寮との規模が比較できる資料はまだ発見されてない。一 方、日本の中世禅宗寺院を代表的な事例である建長寺は、当時の中 国における禅宗伽藍の制度の強い影響が認められている注40)。また 中世の伽藍状況が確認できる「建長寺指図」という史料が現存してお り、主要堂宇の柱間の寸法まで表記されているため、衆寮と僧堂と の規模を比較することができる。なおこれに基づいて、当時の中国 における禅宗寺院の衆寮と僧堂との規模関係も推測できる。
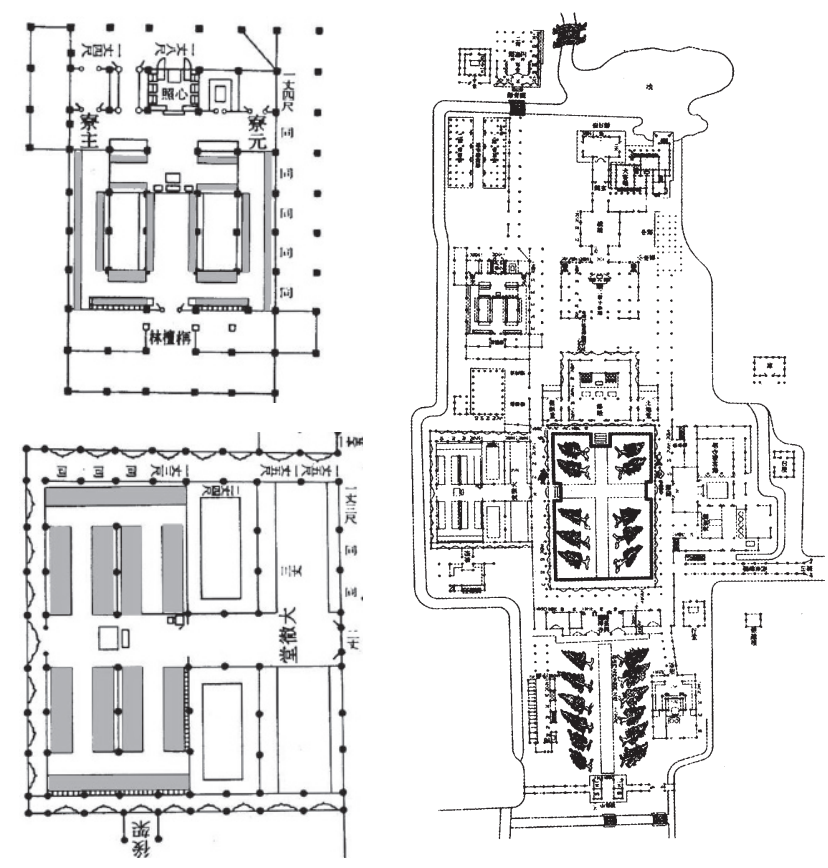

図 3 「建長寺指図」の衆寮 (左上) ・僧堂 (左下) ・ 伽藍配置 (右)

( : 衆寮・僧堂(内堂) の単。図版出典 : 図 2 に同じ)

「建長寺指図」に描かれている伽藍の姿は、創建以来、正和 4 年 $(1$ 315)の二度目の火災の後における再建中であった、元弘元年 (1331) の状況である注41)。衆寮は、法堂の西、僧堂の北側に位置し、「梅檀 林」という額をもつ。これは嘉暦 2 年 (1327)に元僧の清拙正澄 (1274 -1339) が造営したものであり注42)、その規模と制度は中国の霊隠寺 の衆寮と似ていたという注43)。建物の中には東西二箇所の中庭と外 壁に沿って単が設けられ、東西中庭の間の北端部には聖像を安置す
る台座とみられるものがある。後側には寮元・寮主などの役僧の居 房、経典祖録を収めておく「照心」の間注44)などから成る補助空間が あり、把針処もここに設けられていたと考えられる。そして衆寮の 前方には、東西に細長い一間幅の庭(「梅檀林」の字が書かれている部

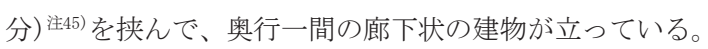

なお、図に書き込まれている柱間の寸法をもって、建物の規模の 他に中に設けられている単の総長も計算することができる。単の総 長は、すなわち衆寮の收容可能人数が把握できる端緒となる。まず、 衆寮の単の総長から計算してみると、単が設けられている柱間の数 は総 24 間であり、各柱間の寸法は 1 丈 4 尺であるから湦46)、単の総 長は約 33 丈 6 尺となる。次に、同じ方法で僧堂の内堂に設けられて いる単の総長を計算すると、内堂の単が設けられている柱間の数は 衆寮と同じく総 24 間であり、各柱間の寸法は 1 丈 3 尺であるから、 単の総長は 31 丈 2 尺となる。

これら衆寮と僧堂の内堂の単の総長を、一人当りに与えられた単 の幅で割ると、それぞれの受容可能人数が算出できる。一人当りの 単の幅は、3 尺と 2.5 尺との二種を想定することができる注47)。この 数字で計算すると、まず一人当りの単の幅を 3 尺にした場合の人数 は、衆寮と僧堂の内堂がそれぞれ約 112 人と 104 人となり、2. 5 尺 にすると約 134 人と 124 人となる。

以上によると、衆寮と僧堂の内堂の受容可能人数が完全には一致 せず、寧ろ衆寮の方は 8-10 人ほど多いが、両方の建築規模を合わせ て計画したことは充分考えられる。また、修行僧たちが僧堂と衆寮 の両方において各自の単位を持っていたとすれば、それらの規模を 合わせて造ることは当然のことであろう注48)。「五山十刹図」の天童 寺配置図には、「妙厳堂」と「照心寮」との二棟の衆寮が描かれている が(図 2、4)、これも同じ理由で理解できる注49)。

\section{4. 伽藍配置における衆寮の位置}

「五山十刹図」の天童寺・霊隠寺・万年寺伽藍配置図 (図 4 6) を見 ると、衆寮は仏殿の西側の、僧堂に近い所に位置する。また僧堂が 伽藍中心の仏殿に隣接して位置するのに対して、衆寮は僧堂の後 (西)或は左・右(北・南)の奥の方に位置する特徴が見られる。なお、 衆寮の向きについては、無著道忠が『禅林象器箋』(第二類「殿堂門」・ 「衆寮」条)で「衆寮之制度南面也」と述べたこととは異なって、僧堂と 同じく東向きが多く、「妙厳堂」・「照心寮」の二棟の衆寮がある天童 寺の場合、「照心寮」が南面するのみである。

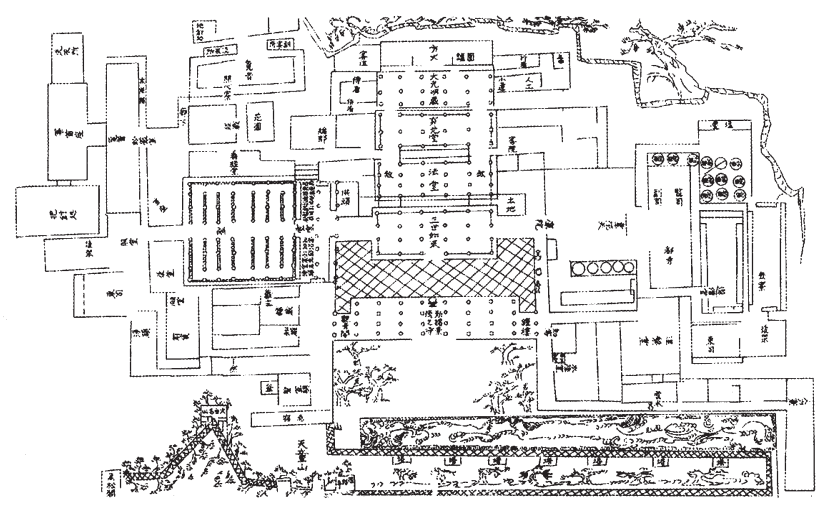

図 4 「五山十刹図」の天童寺配置図(図版出典 : 図 2 に同じ) 


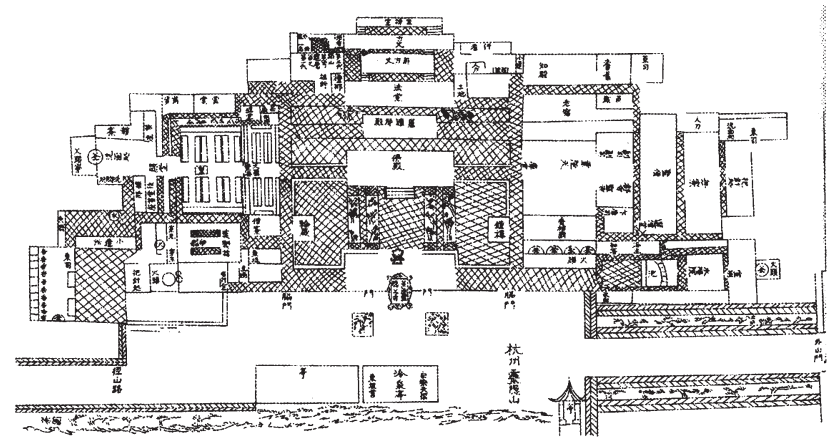

図 5 「五山十刹図」の霊隠寺配置図 (図版出典 : 図 2 に同じ)

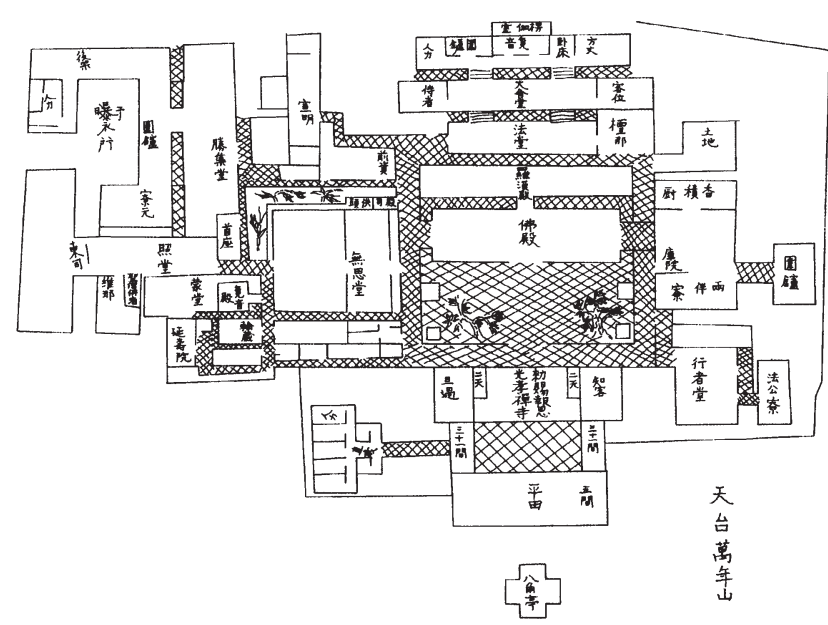

図 $6 「$ 五山十刹図」の万年寺配置図(図版出典 : 図 2 に同じ)

衆寮が伽藍の西側において僧堂に近く位置することは、上述のよ うに禅宗寺院における修行僧の毎日の修行・生活が、主に僧堂と衆 寮で行われていたことと深い関係があると考えられる。しかし衆寮 は、経典祖録の看読のほかに縫物や洗濯、剃髪、合薬など、修行僧 が身の回りのことをする日常生活の場でもあったため、僧堂とは異 なって伽藍中心部から一段退いて配置されるようになったと考えら れる。

一方、宋時代の禅宗寺院には、未だ度牒を得ていない行者たちの 修行と生活の場である行者堂(行堂とも) 注50) と行者寮が存在してい た。北宋の『禅苑清規』(第九巻「訓童行」条)には、「聖僧」が安置さ れている「童行堂」、なおち行者堂注51) と「行者寮」が記されており、 また行者寮においても経典の看読が行われたと考えられる注52)。そ して南宋時代の「五山十刹図」からはある程度の建築的情報を確認す ることができる。

まず天童寺伽藍配置図を見ると、仏殿の東側の庫院のさらに後側 (東)に各々「選僧堂」(西) と「衆寮」(東)と書き込まれている二棟の建 物が立ち並んでいる(図 4)。選僧堂とは、僧堂を正式の僧侶が成仏 に志して坐禅弁道する所の意味で選仏堂」と呼ぶのに対して、行者 が正式の僧侶になるために修行する堂宇の意味であり、すなわち行 者堂のことである注53)。またその東側の建物は「衆寮」と書かれてい るが、これは伽藍の西側にある正式の僧侶のための衆寮(妙厳堂、照 心寮）とは異なる、行者のための行者寮である。これらの選僧堂と衆 寮の南側には東司と後架が連なっている。霊隠寺配置図にも、天童 寺と同様に庫堂の東側に「選僧堂」と「衆寮」があり、選僧堂には聖僧
が安置されており、衆寮の東側には把針処・洗面処・東司が設けら れている(図 5)。万年寺配置図には、庫院の南側に「行者堂」と「法公 寮」とが見える(図 6)。一方、元時代の『禅林備用清規』と『栜修百 丈清規』からは行者堂の存在は確認できるが、行者寮という言葉は 見当たらなくこれの存在は断定し難い。しかし、伽藍配置における 行者堂の位置は宋代と同様に伽藍の東側であったと考えられる注54)

以上のように、宋時代の禅宗寺院には伽藍の西側に僧堂と衆寮が、 また東側には行者堂と行者寮が隣接して立ち並んでおり、それぞれ 僧侶と行者の修行・生活領域を成していた。そして伽藍東側の行者 堂と行者寮の行者が得度して正式な僧侣になると、西側の僧堂と衆 寮へ移ることになる。なおこのように修行僧と行者の修行・生活領 域を伽藍の西と東側に分けて配置することは、宋・元時代の禅宗寺 院を特徴付ける伽藍配置方式の一面として挙げられる。

\section{5. 禅宗寺院における衆寮の成立時期}

上で既に述べたように『禅苑清規』によれば、北宋時代の禅宗寺 院にも「看読の床案」が設けられた衆寮が存在していた。また南宋の 「五山十刹図」に見られる衆寮に設けられていた中庭が、看読のため の採光装置であったとすれば、北宋時代における禅宗寺院の衆寮に も、採光のための中庭が設けられていたと推測できる。

さらに『禅苑清規』第十巻の「百丈規繩頌」条は次のように記す。

・諸寮舍、只得寮主及寮中上座一人、寮內睡臥。

·諸寮舍、不得高声読誦経典、并閑雑文字。自己案分、禅策文字、 常蓋齊整。或把針·剃頭·剪紙·合薬、或曬鞋䩲·觸衣·浴具、皆於 屋後僻処、仍逐時打畳。

ここでの「寮舎」とは後に続く文章の内容からみると衆寮のことであ る。また衆僧が各自の案で経典祖録を看読し、後側には把針・剃髪・ 合薬・洗濯などのための空間が付属しており、「寮主」と「寮上座」な どの役職が止宿しながら管理を担っている。即ち上で考察した宋・ 元時代の衆寮と殁ど差がない。すると「百丈規繩頌」というこの巻題 の通りに、唐の百丈懁海(749-814)の時に、このような衆寮が禅宗寺 院に存在していたともみえる。

一方、『禅苑清規』の「百丈規繩頌」条は、北宋の景徳元年 (1004) 成立の『景徳伝灯録』巻六の百丈伝に収録されている「禅門規式」の 全文と、それに付けられた頌、そして禅院の修行僧が守るべきこと をさらに三十の項目に分けて具体的に記述した「三十件」から成る。 上に引用した文章は「三十件」のうち、第十七件と第二十件に当るも のである。しかし、「百丈古清規」すなわち唐時代の百丈懐海が定め た清規に一部とされる「禅門規式」に記されてない「百丈規繩頌」条の 頌と「三十件」の部分は、『禅苑清規』を編撰した宗賾が新たに加えた ものと考えられている注55)

要するに、現在のところ禅宗寺院における衆寮の出現時期が唐時 代まで遡れるかどうかは断定できない。だが、看読の機能をもち、 把針処などの附属空間を備えた衆寮は、北宋時代には既に成立して いたと考えられる。

\section{6. 結論}

以上で検討してきた、宋・元時代の禅宗寺院における衆寮の機能、 建築構成と規模、伽藍における位置関係、成立時期などを総合的に 考察すると、次のようなことがいえる。 
（1）宋・元時代における禅宗寺院の修行僧は衆寮と僧堂の両方にお いて掛搭を行い、各自の単位が定められていた。そのうち衆寮は経 典祖録の看読の他に、私物の保管や身の回りのことをする日常生活 の場としても使われた。そして南宋時代からは夜の食事(薬石)、楞 峳会、住持の普説(曹洞宗)なども行われるようになった。

(2) 建物のなかに中庭が設けられ、後側に把針処などの補助空間が 取り付かれる形は衆寮の建築構成における特徵といえ、また衆寮の 規模は僧堂の内堂に収容できる人数に合わせて計画されたと考えら れる。

（3）伽藍配置上の衆寮は、伽藍西側の僧堂に近くに位置し、日常生 活の場であったため伽藍中心部から離れた奥の方に配置される。な お南宋時代までには、伽藍東側に正式の僧になっていない行者のた めの行者堂と行者寮が存在しており、行者寮も衆寮と同様に看読の 機能をもち、伽藍奥の方に配置されていたことが確認される。

(4) 看読機能をもち、後側に把針処や衆寮管理の役僧の居房などの 附属空間が取り付く衆寮は、北宋時代には既に成立していた。

宋・元時代の禅宗寺院には、衆僧の修行・生活の場として僧堂と 衆寮の二つの堂宇があり、それらの機能が厳しく区別されていた。 これは、宗覧が『禅苑清規』(第八巻)の「亀鏡文」条で、「叢林の設け、 それを要するにもと衆僧のためなり (叢林之設、要之本爲衆僧)」と述 べたように、修行僧を本位とする禅院伽藍の特徵をよくあらわして いる。

なお、僧堂・衆寮と行者堂・行者寮とがそれぞれ伽藍の西と東側 に配置される現象は、思想的側面から禅宗寺院の伽藍配置が分析で きる一端緒となるとも考えられる。これは今後の課題にしたい。

注

注1）本論文において東アジアという言葉は、宋・元時代に当たる時期におけ る中国、日本および朝鮮半島地域を指寸意味として使った。

注2）駒澤大学内禅学大辞典編篹所編『新版禅学大辞典』2003、p，516。穏澾 和尚が寛政 6 年 (1794) に『永平清規』を重刊(『校訂冠註永平清規』)す る時に、「吉祥山永平寺衆寮筬規」条の後に添えた「衆尞十二板図様凡例」 には、「衆寮者、堂衆飯後之看讀、及平日齋後之喫茶、晚間之哭薬石、 或臨時之行茶湯等。皆於此行之。」と記し、衆寮の機能をよくあらわし ている。大久保道舟編『道元禅師全集』全 (春秋社、昭和 5 年)、p. 672

注3）横山秀哉『禅の建築』(彰国社、1967) pp．191-200。「禅宗伽藍殿堂の 研究」『禅宗建築の研究』第 3 編、東北大学、1958。

注4）横山秀哉、『禅の建築』、pp.191-192。

注5）この図式の名称は、「五山十刹図」(大乗寺本) ・「大宋諸山図」(東福寺 本) ・「支那緒刹図」(永平寺本) ・「大唐五山諸堂図」(常高寺本) ・「禅藍図」 (妙心寺・竜華院本)など、それを所蔵している寺ごとにそれぞれ異なる が、収録の内容には殆ど差がない。ここでは、これらを通称する時は「五 山十刹図」と表記することにする。

注6）代表的な研究成果として張十慶の一連の研究である『五山十刹図與南宋 江南禅寺』(東南大学出版社、南京、2000) と『中国江南禅宗寺院建築』 (湖北教育出版社、2002) が挙げられる。本研究の対象となる衆寮に限っ てみると、張十慶はこれらの研究で、まず衆寮の機能については横山の 説に従って経典祖録の看読が主となる学の道場とし、僧堂に付属する堂 宇とした。しかし、禅院における衆寮の成立時期については追究してお らず、また「五山十刹図」の「衆寮図」の復原平面図を提示し柱間の寸法ま で示しているが、寸法の定め方の根拠は示していない。

注7）『新版禅学大辞典』2003(1967)、p. 162 ; 鏡島元隆・佐藤達玄・小坂機 融『訳注禅苑清規』(曹洞宗宗務庁、1992 (1972))、p. 26

注8)『大日本續藏經』第一輯第二編第十六套第五冊に『重雕補註禅苑清規』 として収録されているが、この論文ではそれの訳注本である、鏡島元 隆・佐藤達玄・小坂機融の『訳注禅苑清規』(上の注 7 参照) を用い、『禅 苑清規』と表記する。

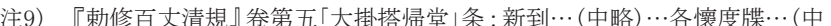
略) …詣堂司 $\cdots$ (中略) ‥参頭與衆、各取度牒、遞付維那 $\cdots$ (中略) …参頭 領衆、前門右手入 (僧) 堂、至聖僧前排立。参頭焼香、同衆大展三拜、巡 堂一匝。…(中略) …行者引至衆寮。鳴内板三下、寮主相接入門 $\cdots$ (中略) ‥
寮主引掛搭人、排列朝観音問訊、引巡案一匝。

注10)横山秀哉、『禅の建築』、p. 192。

注11) 鏡島元隆・佐藤達玄・小坂機融、上掲書、p． $330 ．$ にも、『禅苑清規』 に記されている「看讀床案」は、北宋時代の禅院では衆寮においても看経 が行われたことを示していると述べられている。

注12) 鏡島元隆・佐藤達玄・小坂機融、上掲書、p. 330 。

注13）『大日本續藏經』第一輯第二編第十七套第一冊。

注14）『大日本續藏經』第一輯第二編第十六套第三冊。

注15）『大日本續藏經』第一輯第二編第二十六套第一冊。

注16）『大正新修大藏經』第五十一巻(「史伝部」三)および中華電子佛典協會 (CBETA) の電子仏典。

注17) 上の注 13) に同じ。

注18) 安居とは、雨安居の略で、インドにおいて三月間の雨期に発生する草 木・小虫などを殺傷しないように、一籄所に集合して禁足し、坐禅修学 することに始まった。これによって一夏九旬・九旬禁足・結制安居・結 制などと称し、結制安居の始まることを結夏といい、終るのを解夏とい う。またこの制によって僧侣の戒臘( (法臘) 位階を定め、第一夏を入衆と し、五夏以上を闍梨、十夏以上を和尚と称する。一方、中国では江西・ 湖南の修行僧が集合して結制を行ったことから、結制を江湖会とも称寸 る。また夏冬の二安居が採用されたのも中国からである。『新版禅学大 辞典』p. 12 。

注19)『新版禅学大辞典』p. 1284。

注20）『叢林校定清規総要』巻上「衆寮解結 $\mid$ 条 : 四月十一或十三日。…中 略) …至晚。安排照牌。先就衆寮內、特為夏中執瓶亚兄弟喫湯。請寮長 相伴。次排大衆照牌。鳴寮前板、衆集。寮主・副寮行礼。如知事特為新 到一同。湯罷、打退座板、維那謝湯。寮元便出寮門右辺、接住持・知事・ 頭首外寮人入。却建楞厳会。寮主舉経回向而散。解夏礼同。

これと『禅林備用清規』巻之三「衆寮楞篇」条と『栜修百丈清規』卷第七 「衆寮結解特為衆湯】条の内容は大同小異であるが、衆寮における解結の 日は4 月 12 日(結夏)および 7 月 12 日(解夏) となっている。

注21）『叢林校定清規総要』巻下「建散楞厳会」条：仍隔日、詣方丈請薟疏。斎 罷、挂牌、預提点大仏殿香燭。至期 $\cdots$ (中略) …住持至仏前、焼香一炷、 退身問訊、展拝踭炉。知客度炉、侍者棒香合、住持上香、維那白仏云 $<\cdots$ 割注略 $\cdots$. 次宣疏異、知客接炬、住持起身、楞厳頭喝楞厳会上、衆和 畢。楞厳頭即唱爾時世尊云云。舉䶸喝摩訶了、維那再回向云 $<\cdots$ 割注略 ‥ $>$ 大衆無抹。

注22）『叢林校定清規総要』卷上 $\lceil$ 頭首衆寮點江湖茶 $\rfloor$ 条 : 頭首夏中衆寮點茶 当日张罷、令茶頭行者請寮元寮主、并挂牌。寮元・寮主、於観音前、分 手坐。點茶人、設位於寮門内上手。與寮元、対面而坐。齋退、行者即鳴 尞前版。點茶人、先往寮門外下手、合掌立揖。衆入畢、焼香三炉、転中 間炉前上手、問訊寮元。次転下手、問訊寮主。復転上下間炉前問訊。仍 帰中央、問訊立。寮元起身、揖請點茶人坐。喫茶畢。點茶人起身、帰中 下手立。寮元出炉前、謝茶、送出。

中国では夏安居を結ぶことを江湖会と称したので(上の注 18 参照)、「江 湖茶」とは「夏中」、即ち夏安居中に喫する茶湯のことであろう。

注23）『禅苑清規』第二巻「結夏 $」$ 条 : 四月十四日。齋後、掛念誦牌。至晚、知 事豫備香花法事。於土地前集衆念誦。および同 巻二の「解夏」条：七月 十四日晚。念誦・煎湯、來日陡堂人事寮舍煎點並同結夏之儀。

注24）普説とは、住持の法堂における正規の上堂説法以外飞、随時に行われた 説法の一種である。『禅林象器箋』(第十二類「垂説門」・「普説」) によ ると、普説は北宋後期の真浄克文(1025-1102) より始まったという。し かし、北宋の『禅苑清規』(1103 年)には、まだ普説という名称自体が見 られず、南宋に入ってから禅宗寺院に広く普及することになったとみら れる。清規によれは、普説は南宋代までは寝堂で行われたが、元代には 法堂においても行われるようになる。しかし、衆寮における住持の普説 は一般的ではなかった。なお、南宋時代の禅宗寺院における普説の場所 として使われた寝堂という堂宇については、先行研究が極めて少なく、 未だ不明な点が多い。

注25）行李には大きく二つの意味があり、その一つ目は僧侣の修行の経過・行 状の意で、この時は「あんり」と読み「行履」とも書く。二つ目は雲水行脚 僧が携行する荷物入れの意で、この時は「こうり」と読む。ここでは後者 の意味に従う。『新版禅学大辞典』p. $17 ;$ p. 327 参照。

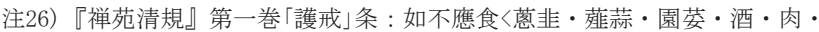
魚・兔、及乳餅・酥酪・用蠐蝶卵・猪羊脂、立不應食。如遇病緣、寧捨 身命、終不以酒肉俗味毁禁戒〉、非時食〈小食薬石與果子・米飲・壹湯・ 菜汁之類、如非齋柅二時、竝是非時之食也〉、並宜服禁。(〈 : 割注、以 下同じ)

注27)放参とは、晚参(晚間に宗師家に参ずること)を休むことであるが（『新 版禅学大辞典』p. 1129)、清規によると、南宋・元時代には、晚参を行 った場合も、後に衆寮に帰って薬石を摂った。

注28) 和南とは、梵(巴) 語 vandana の音写で、意訳は敬礼·恭敬·度我など。尊 敬をささげることで、税首、また敬礼して口に唱える語の一をいう。『新 版禅学大辞典』p. 1326 。

注29) 眠単、すなわち布団をのべること。『新版禅学大辞典』p.896。

注30)『禅林備用淸規』巻之二「坐参」条 : 放参䐖熟、堂司行者覆首座放参。行 者転弇後、右出前門。鳴僧堂前鐘三下、住持出堂、次首座衆頭首出堂。 
大衆和南問訊、下床、各出半単。帰衆寮喫粥。… (中略) …放参、住持頭 首同帰衆寮薬石。今也不然、甚失古意。

注31）『栜修百丈清規』巻第六「坐参」条：堂司行者、候晚弹熟、覆首座云〉放 参〉。転聖僧後、右出下牌。鳴堂前鐘三下。衆就位、普同和南。住持頭 首次第出堂。衆下床、各出半単。前輩住持頭首、亦同帰衆寮薬石。蓋古 者毎晚必参住持、以求開示。故率衆齊集坐待、鼓鳴而往参。之名曰坐参。 因汾州地寒、昭公罷之、遂有放参之設。

注32）上の注 30 (放参、住持頭首同帰衆寮薬石。今也不然、甚失古意)および注 31 (前輩住持頭首、亦同帰衆寮薬石) 参照。

注33) 南宋の『叢林校定声規総要』(巻下「坐禅・坐堂・放参」条)によると、修 行僧たちは、一日四回、寸なわち朝食後、昼食後、また夜間の初夜と深 夜の三鼓 (三更：0-2 時)の時に、僧堂に集まって坐禅を行ったことが分 かる。

注34）上の註 27 参照。

注35）『雪厳祖欽禅師語録』卷第二「普説」条：山僧、五歳出家。…(中略) …十 六歳為僧。十八歳行脚。…(中略) $\cdots$ 在双林鉄橛遠和尚会下、打十方。從 朝至暮、只在僧堂中、不出戶庭。縱入衆寮、至後架、袖手当胸、徐來徐 往。更不左右顧。目前所視、不過三尺。『雪厳祖欽禅師語録』は元の大 徳二年(1298)に昭如、希陵などが編集した。『れ新纂續藏經』巻七十(「諸 宗著述部」十七)および中華電子佛典協會 $(\mathrm{CBETA})$ の電子仏典に収録

注36）現在のところ、「五山十刹図」の作製年代については、「三八念誦の回向

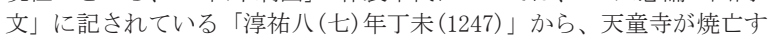
る宝祐四年 (1256)の間の作製とみる横山秀哉の説(「支那禅刹図式の内 容」『禅の建築』pp.46-66) が最も有力である。

注37) 現在この衆寮は金山寺の衆寮とも知られているが(横山秀哉、『禅の建 築』; 『新版禅学大辞典』; 張十慶、上掲書など)、実際「五山十刹図」には 寺名は勿論、図名も書かれていない。一方、無著道忠が享保元年(1716) に図写を完成した図式(妙心寺・竜華院所蔵、「禅藍図」)の「目録」のとこ ろには、ただ「衆寮図」と書かれている。

注38)「五山十刹図」には各寺院の堂宇の額を集め、主要堂宇の種類別に整理し た「諸山額集」という項目があり、これにより伽藍配置図から衆寮の位置 を確認することができる。

注39)これに対して、一般の修行僧たちは、僧堂の「内堂」において坐禅・食事・ 睡眠まで行った。すなわち、宋・元代の禅宗寺院における僧堂は、外堂 と内堂から成り、外堂と内堂との間に中庭が設けられているのが、一般 的な形であった。また、役僧たちの坐禅・食事の場である外堂の単は、 睡眠の機能がないため、内堂の単より幅が短い。日本の場合、「建長寺 指図」の僧堂にこのような構成が確認される。なお 13-4 世紀の中国・日 本さらに韓国の禅宗寺院における僧堂の建築構成と特徵に関しては、横 山秀哉『禅の建築』、鈴木智大「南北朝期の五山叢林における僧堂生活の 実態」(『日本建築学会計画系論文集』第611号、2007 年1月、pp. 183-188) 韓志晚「韓国における桧嚴寺跡の僧堂遺構について一東アジア禅宗史か ら見て一」(『日本建築学会計画系論文集』第 602 号、2006 年 4 月、pp. 219-224)などを参昭すること。

注40) 太田博太郎『社寺建築の研究-日本建築士論集III-』(岩波書店、1986) pp. 186-187 ; 関口欣也『五山と禅院』(小学館、1991) pp．149-159; 藤井恵 介「2.1.1 鎌倉の寺院建築」『日本建築史一新建築史大系-』(彰国社、 1999) p. 197. などによる。

注41) 関口欣也「建長寺指図」(『神奈川県文化財図鑑-建造物篇』神奈川県教育 委員会、1971)、p. 185。

注42)「清拙大鑑禅師塔銘」には、「大元泰定丙寅八月、至博多。明年正月、上 京。関東使來、迎居建長。三月二日入寺。檀信禀以大国禅林所宜行事。 審擧行之。師開堂、告香普説。新造衆寮。規製如霊隠者。」とあり(『続 群書類從』第九輯下・「伝部」巻第二百三十)、また『扶桑五山記』には、 「衆寮虹梁銘 $\cdots$ (中略) $\cdots$ 嘉暦〈丁卯〉十二月十六日鼎建 $\cdots$ (中略) $\cdots$ 住山正 澄題」とあり、嘉暦 2 年(丁卯、1327)に正澄が衆寮の梁銘を書いている。

注43) 上の注 42 参照 (規製如霊隠寺)。さらに、「建長寺指図」の衆寮の額名は「梅 檀林」、南宋「五山十刹図」の霊隠寺の衆寮は「旃檀林」である。「梅檀」は 「旃檀」とも書く。

注44「建長寺指図」には「心照」と書かれているが、これは「照心」の誤記であろ う。照心とは、修行僧が経典祖録を看読して照心古教、すなわち先得古 仏の教示を鏡とし、自己の心行をうつし、自ら省察する意味である。し たがって、経典祖録を看読する衆寮を「照心寮」とも称する(以上『新版 禅学大辞典』p. 561 参照)。「五山十刹図」によると、天童寺には 2 棟の 衆寮があり、そのうち一棟の額名は「照心寮」であった。

注45) 衆寮内部における入口の東西両側に設けられている単の採光のために は、この部分が外部空間となる必要がある。

注46）南側の門の東西の単の場合、一間より長いが、その長さを正確に測るこ とはできない。ここでは計算の便利上一間 (1丈 4 尺)の長さとして総長 を算出した。

注47)『禅林象器箋』(第二類「殿堂門」・「三條橡」条)には「僧堂之床、毎人座 位、橫占可三尺許」と記されている。また「五山十刹図」に収録されてい る南宋の径山寺僧堂の平面図と僧堂坐床図を比較して分析すると、一人 当りの単の幅が「二尺五寸」であったと考えることができる。詳しくは、 韓志晚の上掲論文 (注 39) を参照。

注48)さらに、近世の史料ではあるが、寛政 6 年(1794)に『永平清規』を重刊
する際に添えた、「衆寮十二板図様凡例」には、「夫衆寮者、堂衆飯後之 看読、及平日齋後之喫茶、晚間之喫薬石、或臨時之行茶湯等。皆於此行 之。然則衆寮從僧堂之大小。而亦当有広狹焉。僧堂若十二板、則衆寮亦 必当十二板。僧堂若十六板、則衆寮亦必当十六板」とあり、確か衆寮と 僧堂(内堂) との規模を一致させようとする意識はあったと考えられる。 出典は上の注 1 に同じ。

注49)「五山十刹図」に描かれている天童寺伽藍(図 4) は、南宋宝祐 4 年(1256) に伽藍が炎上する以前の、建炎 3 年 (1129) から紹興 27 年 (1157) 示寂す るまで住持を勤めた宏智正覚(1091-1157)によって一新された状況であ る。正覚は住持の在職中に、山門の前方に大池を二箇所掘りその間に七 塔を配し、重層山門の千仏閣と盧舎那閣を建て、また大僧堂を建立 (1132-1134) した。天童寺は正覚の入寺によって、それまでの衆僧二百 から千二百という盛況を迎えたという（以上は関口欣也「中国江南の大 禅院と南宋五山」『仏教芸術』144 号、1983、p. 15．を参照)。一方、正 覚自記の「明州天童山景徳寺新僧堂」(東福寺所蔵の宋拓、他に清嘉慶間 (1796-1820) 重刊の『天童寺志』、『讯新纂續藏經』などにも収録)には、 新築された大僧堂の規模について、「前後十四間、二十架。三過廊。両 天井。下無墙陼(堵力)。縦二百尺、広十六丈。空牌牀榻、深明厳潔。万 指食息」と記している。そのなかで「前後十四間、二十架」とは、桁行 14 間・梁行 10 間の意味で、それらの寸法が「二百尺、広十六丈」であった とみられる。「両天井」とは、内堂と外堂との間に設けた中庭のことで、 「三過廊」は内・外堂を繋ぐ三つの廊のことと考えられる。また「万指食 息」の「万指」は、千人の衆僧の意味であろうか。「妙峳堂」・「照心寮」の 二棟の衆寮の建立年代は確認できないが、これは新築された大規模の僧 堂に合わせて新築或は改築された結果として考えたい。

注50) 北宋の『禅苑清規』には「童行堂」、南宋の『叢林校定清規総要』および 元の『禅林備用清規』と『栜修百丈清規』には「行堂」と記している。一 方、「五山十刹図」には「諸山額集」のところに「行者堂」という項目の下に 「選僧堂、盧隠堂、天慧堂、浄心堂」と額名を列記しているが、いずれも 同じものを指しており、この論文では「行者堂」と表記することにする。 そして、南宋時代の禅宗寺院における行者堂の存在を指摘した既往研究 としては、横山秀哉『禅の建築』(p. 219) と永井規男「中世五山におけ る庫院とその変容」(『建築史学』第 38 号、2002.3、p.10)などがある。

注51) 宋代には出家(童行) と得度 (沙弥) との間に判然たる区別があり、仏門に 入るものは先ず許されて入寺し、童行となることを必要とした。童行は 出家者の関門であるからこれを出家と称し、出家には父母の承諾を必要 とした。童行は寺内の童行堂に住し、沙弥として必要な経典の読誦や、 諸法式やその他の訓練を受けるとともに、寺内の雑役に従事し、方丈行 者・客頭行者・堂司行者・監作行者などと呼ばれた(以上、鎌田茂雄『中 国仏教史』岩波書店、2006(1978)、pp. 283-284)。即ち童行堂とは行 者堂のことである。

注52）『禅苑清規』第九巻「訓童行」条 : 新到童行、於庫司参礼記、将行李入童 行堂。参礼堂主竟、堂主掛搭、并指床位 $\cdots$ (中略) …晚参後、不得過堂西 并堂頭・庫下・行者寮・作務処所 $\cdots$ (中略) $\cdots$ 不得床上立地着衣。不得背 聖僧上床…(中略) …看経寮舍、令打畳浄潔。

注53)『新版禅学大辞典』p. 694 参照。

注54) 永井規男は、上掲の論文 (注 50) で、南宋時代の禅宗寺院における行者堂 が伽藍東側の庫院に隣接して建てられる理由について、行者堂が寺院の 僧籍に正式に登録されていない僧などが居留するところで、その意味て は半世俗的な性格をもつことになり、それを扱うのは世事を扱う庫院が その任にあたるのが適切であるためであると考えた。

注55）鏡島元隆・佐藤達玄・小坂機融、上掲書、p，341; 石井修道「百丈清規 の研究-「禅門規式」と『百丈古清規』一」(『駒澤大学禅研究年報』第六号、 駒澤大学禅研究所、1995 年 3 月) pp.44-45。なお石井修道は同論文で、 百丈懷海の編著になる成文化した『百丈古清規』は存在しなかったと結 論付けている。

（2007年 7 月 9 日原稿受理，2007年12月17日採用決定） 